\title{
THE ARCHITECTURE OF IBADI MOSQUES IN M'ZAB, DJERBA, AND OMAN
}

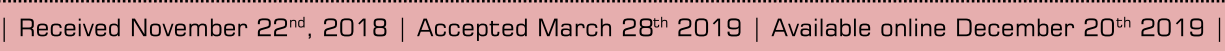

\section{Naima Benkari}

Department Civil and Architectural Engineering Sultan Qaboos University

Oman

nbenkari@squ.edu.om

\begin{abstract}
The Ibadis are a Muslim religious minority with a long history and a rich philosophical and theological literature. This research claims that the lbadis adherence to strict and puritan Islamic principles has not only affected their individual and social behavior, but also marked their approach to architecture, and the construction of cities. This article investigates the architecture of mosques developed in the four significant regions where this network of communities has settled since the ninth century: Oman, the M'zab valley in Algeria, Djerba in Tunisia, and Jebel Nafusa in Libya. Many features distinguish the architectural style of these from the typical mosque style. Although it may appear plural in its spatial arrangement, volumes, material and construction methods, the architecture of Ibadi mosques displays an "air de Famille" that relates them to their Arab-Berber origins and Ibadi religious principles. The present research is a comparative analysis of representative samples of this architecture in all the regions inhabited by the lbadis. The second layer of scrutiny consisted of exploring the origins of its distinctive features in the meanings of the Ibadi Fiqh that concerned the act of building. It is a pioneering investigation of the relationship between the lbadi religious principles and the architecture of their mosques. This research has established that the lbadi Fiqh has addressed some aspects of the design of mosques and therefore have impacted, if not produced, some of the distinctive features of this architecture.
\end{abstract}

KEYWORDS:

Ibadism; Ibadi jurisprudence; mosque; Mihrab; minaret; Minbar

\section{INTRODUCTION}

Ibadism is among the earliest schools of Islamic thought, which formation started in the seventh century CE (17th C.). It was first active in Iraq where this doctrine was born; it then spread to other regions of the Mashreq, settled in the Maghrib with the birth of the Rustemid Imamate of Tahart in Algeria and finished its course in the area of M'zab. Today, the Ibadi School has followers in four main regions of the Islamic world: the Sultanate of Oman, the M'zab valley in Algeria, the island of Djerba in Tunisia, and Jebel Nafusa in Libya [1]. In the Maghrib, since the decline of the Rustemid imamate in the tenth century (10th C.), Ibadis became a minority group in Islam, especially after their persecution by the Fatimid Shi'a and then the Sunni states that followed.

Nowadays, the Ibadi community in Algeria is a minority in both ethnic and religious terms. Due to this situation, which was exacerbated by continuous persecution, the lbadis had to retreat into the farthest and most arid zones in the country, where they have survived for centuries. In order to protect themselves and preserve their beliefs and rituals, the Ibadis had a strong religious hierarchy, which generated a solid social cohesion throughout the ages. They also had a continuous and extremely fertile intellectual produc- tion in the form of thousands of manuscripts [2]. The architecture was another mean through which the Ibadis expressed their beliefs and principles. Over the past century, researchers have investigated the Ibadi architecture, focusing mainly on the M'zab. Most of those studies concentrated on the city and its organization [3] and vernacular habitation [4] [5]. The topic of the Ibadi mosque and other spaces of worship was also investigated [6] although in a much less proportion. These studies were descriptive or historical and essentially fragmented, isolating the Ibadi architecture of the Mashreq from its equivalent in the Maghrib.

The objective of the present article is to analyze the Ibadi religious architecture in the four regions where this community settled for centuries and still lives today. This architecture distinguishes itself from "classical Islamic architecture" in several characteristics, which will be described and discussed. Although this architecture is plural (in its spatial organization, volume, materials, and construction details), it possesses a sort of "air de Famille" that characterizes it.

\section{METHODS}

The study presented in this paper emanated from this observation and tried to explore and analyze 
comparatively a representative selection of Ibadi mosques from the four identified regions: M'zab, Djerba, Nafusa, and inner Oman. The mosques, which were studied in this paper, were selected through field visits, on-site observations, literature investigations, and interviews with Ibadi scholars in history and religious studies. The comparative analysis was focused on the architectural composition and features of the mosques in order to identify the stylistic continuities and interruptions in this selection. To explain the results of this analysis, and interpret the observed distinctive properties of these mosques, the author undertook an investigation in the Ibadi jurisprudence related to the construction maintenance and management of mosques [7]. It is for the first time that an approach has been applied to the study of the Ibadi mosques ever since research has been devoted to this topic. The main findings of this investigation attribute this unity, in the architecture of the Ibadi mosques, mainly to the Berber culture of this community as well as to a corpus of rules and construction principles generated from Ibadi precepts and which governed the development of this architecture. The research has also unveiled some instances where the architecture distanced itself from the religious laws governing it. The paper presents attempts of interpretation of these differences and opens the reflection on further investigations.

\section{DISCUSSION}

\section{AESTHETIC VALUES OF RELIGIOUS IBADI ARCHI- TECTURE: MODEST FORMS, HUMAN-SCALED PRO- PORTIONS, ABSENCE OF ORNAMENTATION}

A close look at the mosques that were built by Ibadis in the four regions shows that the constructions designated for formal prayer are, in fact, very simple with pure forms and occupying, in general, a quite limited area. These mosques do not have any ostentatious features. Their façades, covered with lime, are punctuated only by small openings and slit windows (Figures 1-4). An excellent uniformity characterizes the spaces of these structures. Columns and walls, bare of any ornamentation, support the low and equally unadorned roofs. The Ibadi mosque, no matter how prominent its status, is not ornamented. It consists of only pure forms and smooth walls covered with lime and rarely painted [8] (Figure 2).

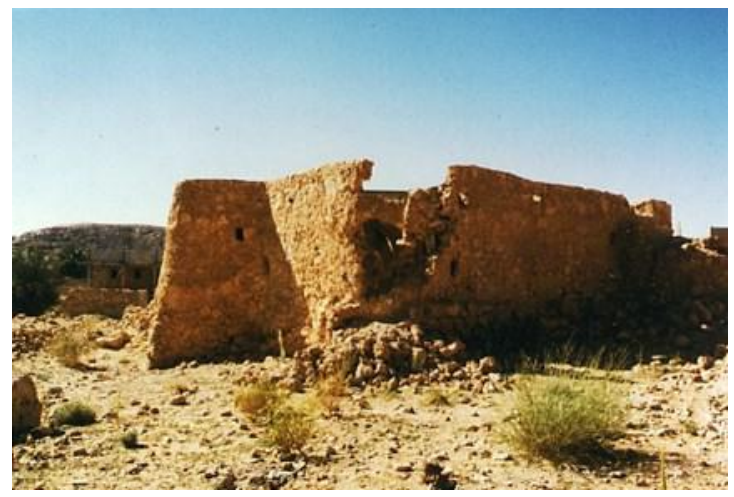

Figure 1. Aouel-Aouel Mosque, El Ateuf, M'zab.

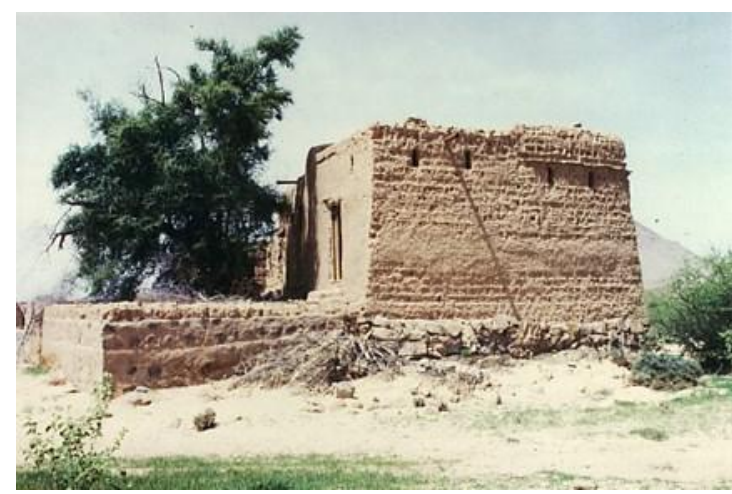

Figure 2. Mosque in A'Sharqiyah region, Oman

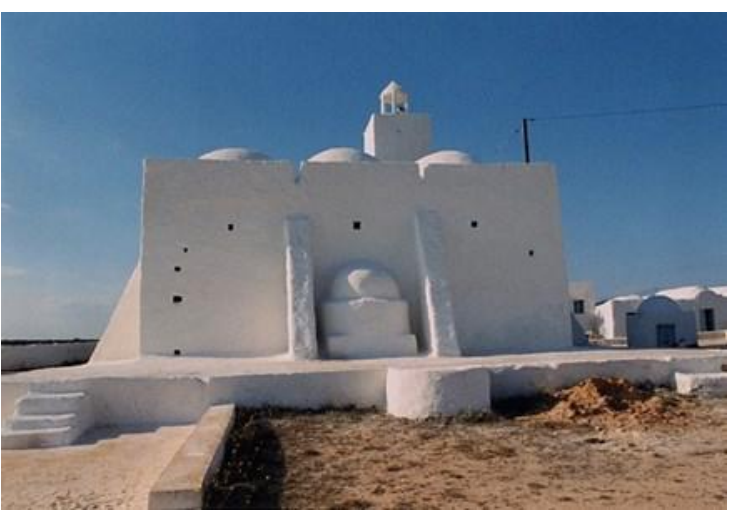

Figure 3. Exterior view of Mihrab in the Qibla wall.

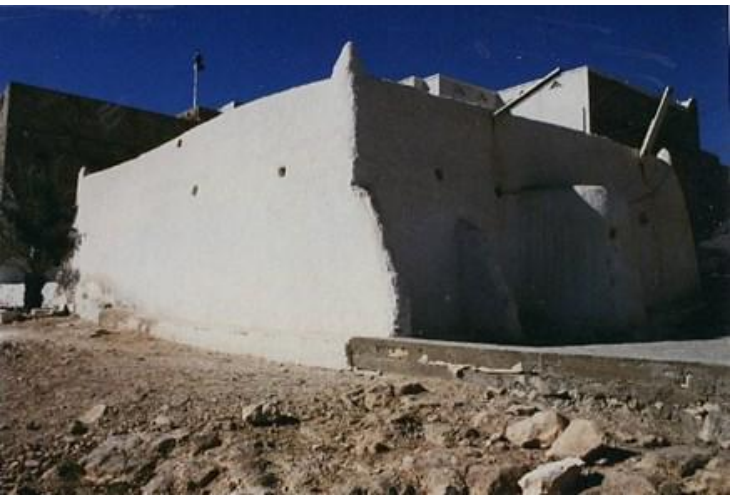

Figure 4. Agherm Wadai Mosque, Melika

Figures 1-4: Ibadi mosques in Oman, M'zab, and Djerba

The consideration of the human proportion is one of the most evident particularities of this architecture. According to Mrabet, it is one of the aspects through which a researcher comprehend the aesthetic of Ibadi architecture [9]. The proportionality of this architecture's spaces reflects its coherence and the importance it gives to the human being [10]. The reference to the human proportion, which directly relates to the concept in Islamic theology that the human being is the noblest and most complete of creations, has endowed this architecture with some unique and beautiful proportions. The modest dimensions of its spaces are the source of the humble appearance of this architecture and reveal the substance and the aesthetic values of its builders [11].

174 | Journal of Islamic Architecture, 5(4) December 2019 
In reality, these characteristics are not exclusive to Ibadi architecture but impregnate any vernacular architecture. Most researchers who have noted these particularities in Ibadi structures in the Maghrib consider that they are due to the Berber origins of the builders and the use of local materials for construction [12] Furthermore, the Ibadi mosques of the M'zab or Djerba are considered as a representative model of the religious architecture in the Saharan belt that borders the territory of the Arab Maghrib [9] [13].

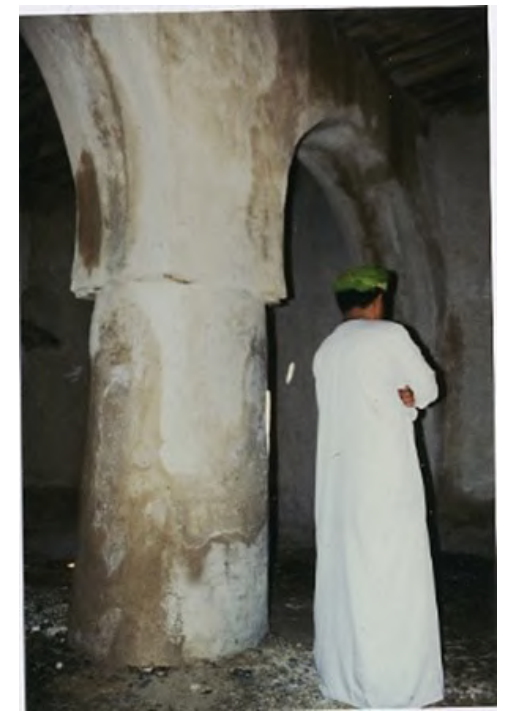

Figure 5. Interior of a mosque in A'Sharqiyah, Oman

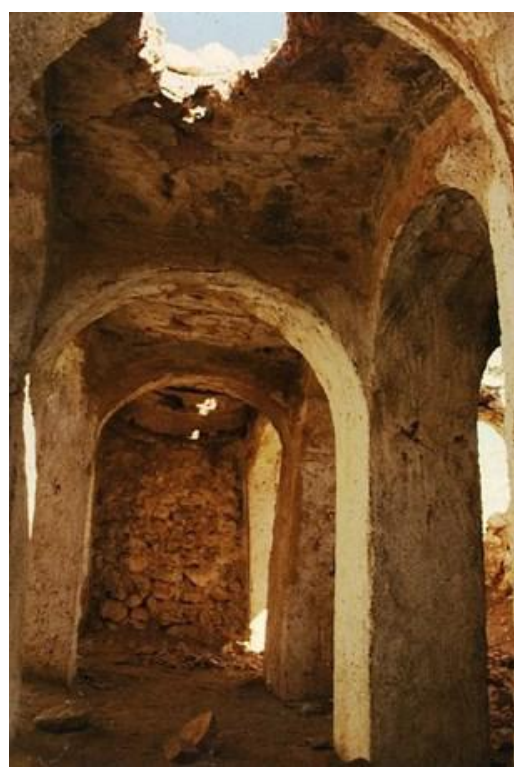

Figure 6. Interior of a mosque in Djerba, Tunisia Figures 5 \& 6: Mosque interiors in Djerba and Oman

On the other hand, without neglecting this aspect, other researchers have claimed that the great simplicity of this architecture is undoubtedly linked to the profound religious spirit of both its builders and its users [9] [14] [15] as well as to the social rules of this community [4] [8]. The forms of the Ibadi mosques in the M'zab, Djerba, Nafusa, and central Oman seem to mimic the model of the first mosques of Islam. Ibadism is a school that defends the principles of equity and calls for the application of the precepts of Islam, as revealed in the Qur'an, interpreted through the Sunna of the prophet Muhammad and applied by his close companions. Therefore, the Qur'an and this Sunna are the foundations of the Ibadi doctrine. It is a puritan and conservative doctrine that rejects the innovations that could lead the believers away from the ascetic path of the prophet and his companions.

It is in the spirit that Ibadi jurisprudence directs and regulates the different aspects of community life, including the art and work of building. Indeed, the opinions of the Islamic legal scholars, Ibadi or Sunni, are unanimous about taming the spirits of domination and arrogance that tend to be expressed throughout proportioned constructions, where the risk of depleting materials and goods is high [15]. The mosque, a structure essential in any built environment produced for Muslim communities, must incarnate this principle of simplicity so crucial to the Ibadi doctrine. This tenet is at the origin of the unchangeable simplicity of Ibadi religious architecture.

However, this minimalist principle is, at times, countered by some notable exceptions. The first lbadi mosques of Tahart and Sedrata (Isedraten), as well as those of Ouargla, were ornamented, and as such stand out from the later Ibadi mosques in M'zab, Djerba and Nafusa [12][17][18][19]. Similarly, the character of simplicity and sobriety, manifest in the absence of any attempt at ornamentation in most of the traditional mosques of Oman, is in sharp contrast to the refined adornment that appears in the Mihrab (prayer niche) of the few exceptions to this model. Ornamentation of the prayer niche was a trend that appeared in the thirteenth century and ended in the eighteenth century, and within a limited territory in the interior regions of Oman (Figures 7-9).

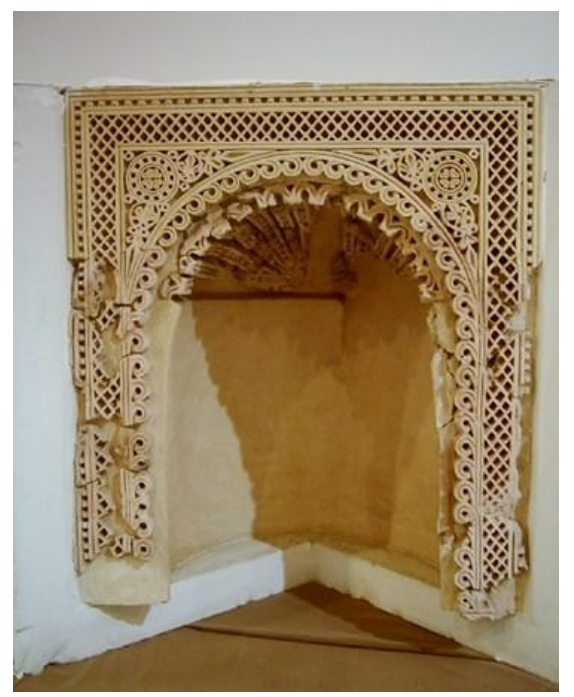

Figure 7. Ornamented fragment discovered in Sedrata (Courtesy of A. Moussaoui) 


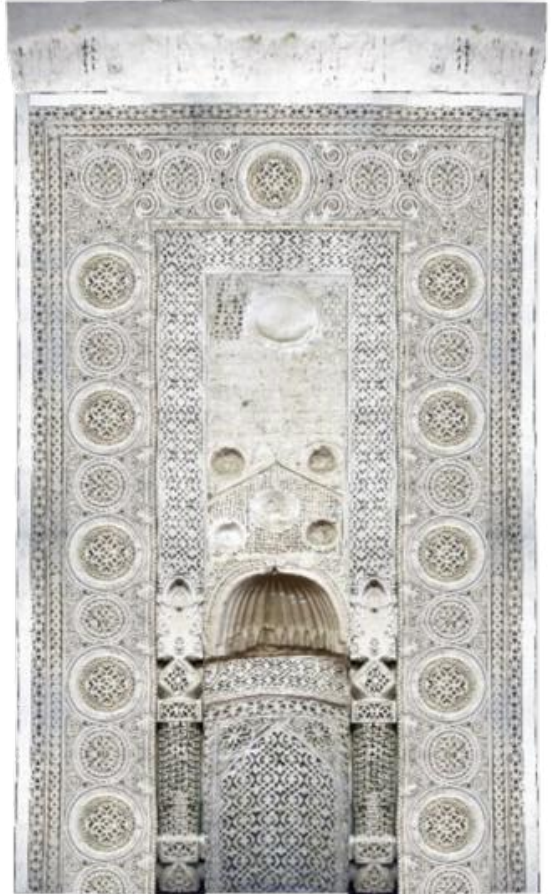

Figure 8. Decorated Mihrab of Masjid al-Gharidh, Nakhal, Oman

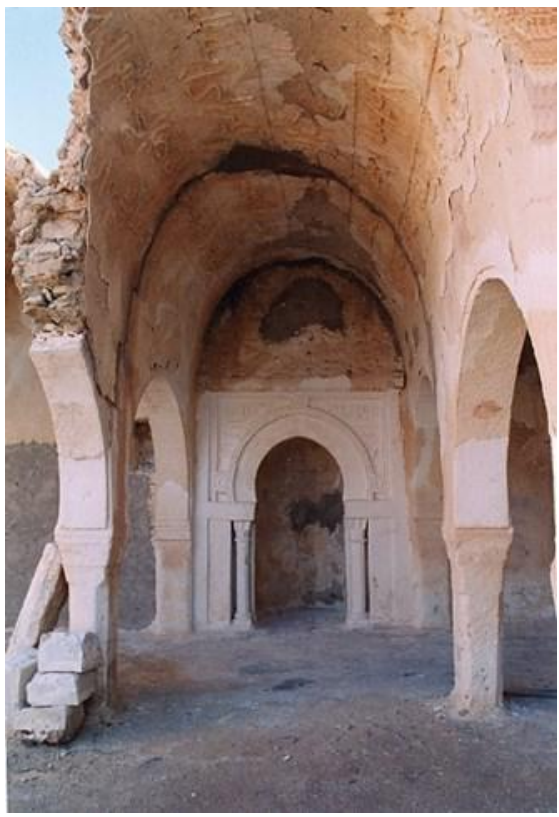

Figure 9. Decorated Mihrab and vault, Djerba Figures 7-9: Ornamentation in Ibadi mosques

\section{HOW COULD ONE EXPLAIN THOSE EXCEPTIONS TO THE FORMULATED PRINCIPLES OF SIMPLICITY IN IBADI RELIGIOUS ARCHITECTURE?}

Marcel Mercier, who was the first researcher who makes a note of this interruption in style of the Ibadi mosques of Tahart and Sedrata, argues that in contrast to their ancestors, the Ibadis of M'zab were no longer steeped in their Arab culture. Instead, they had drawn closer to the Berber culture of their parents and grandparents [20]. This shift was emphasized by the nature of the environment in which the Ibadis had settled: the arid and inhospitable region of the M'zab valley. From a historical perspective, this scenario is supported by the theory posited by the French architect Henri Saladin in 1907 about the beginning and maturation of Islamic architecture in the Maghrib [21]. According to Saladin, until the eleventh century, this style was tightly linked to the Middle Eastern origins of Islamic architecture. This process could have taken place in the same way with Ibadi architecture, but it is worth mentioning that even in the M'zab, the early builders had not entirely assimilated into the Berber culture. Instead, there was a multicultural population united by their Islamic beliefs and Ibadi practices. The builders of the M'zab were the direct descendants of those who had built the mosques and palaces of Tahart and Sedrata.

\section{HOW COULD ONE EXPLAIN THIS INTERRUPTION BE- TWEEN THE ARCHITECTURE OF THE IBADIS IN THE M'ZAB AND THE ARCHITECTURE OF THEIR PREDECES- SORS IN TAHART AND SEDRATA?}

The state of kitman (secrecy or covertness) in which the Ibadi community of the M'zab had to function after having left Tahart is another aspect of the social reality of the Ibadi Mozabites [18]. It could have also affected the way these people were doing their architecture in both M'zab and Djerba. The new social organization developed by the Ibadi scholars and leaders of M'zab added to the need to live in hiding to avoid persecution and invasion from the north, have inevitably and deeply affected the architecture of this region [18]. This new architecture, simple, modest, and strongly influenced by its natural context, could also have borrowed some of its features from the architecture of the indigenous Berber tribes who had converted to Ibadism [18].

\section{THE “FRAGMENTED” GENERAL ORGANIZATION OF THE IBADI MOSQUE}

The Ibadi sanctuaries studied here are composed of two to three prayer spaces attached or detached from each other but linked together with an open courtyard. This composition seems without formal coherence. It is very different from the spatial composition of what is known as the Maghribi style of mosques, which exhibit regular forms and coherent compositions. It seems that the rule in the Ibadi mosques is to have an enclosed prayer room [20] surrounded and bordered by a courtyard, which latter also functions as an open-air prayer space. This courtyard, which could take any form, is the element that links all the other areas of the mosque with the enclosed prayer room (Figures 10-12). In the first mosques erected by the Ibadis in the Maghrib, the closed prayer rooms do have regular forms of a cuboid with square or rectangular plans. It is the case with the traditional mosques in Oman. However, the mosques of the M'zab present a variety of forms in their prayer rooms and courtyards. Flexibility in the forms and originality in the volumes is what made the fame of the 
Ibadi architecture in M'zab (Figures 10-12). Interestingly, the most recent extensions of those mosques and newly constructed mosques tend to have more regular forms and coherent spatial organization [8] [20]

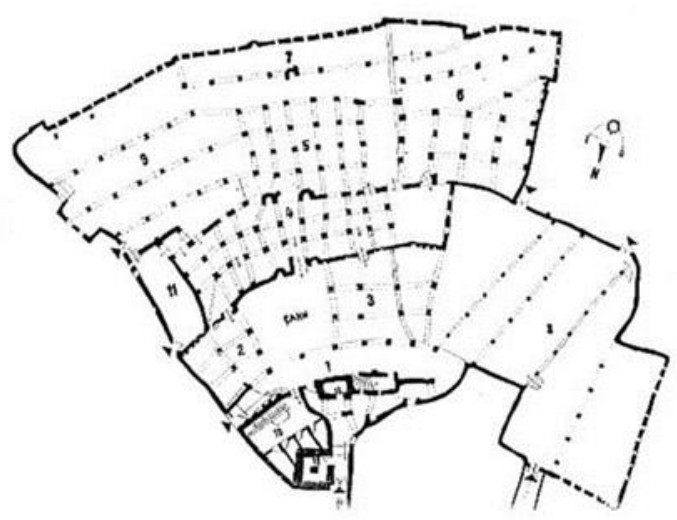

Figure 10. Great Mosque of Ghardaia, M'zab

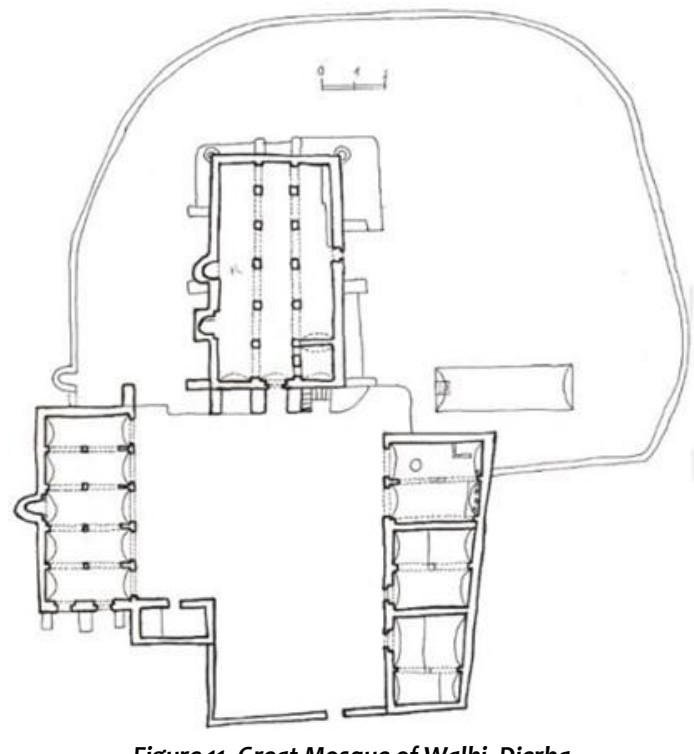

Figure 11. Great Mosque of Walhi, Djerba

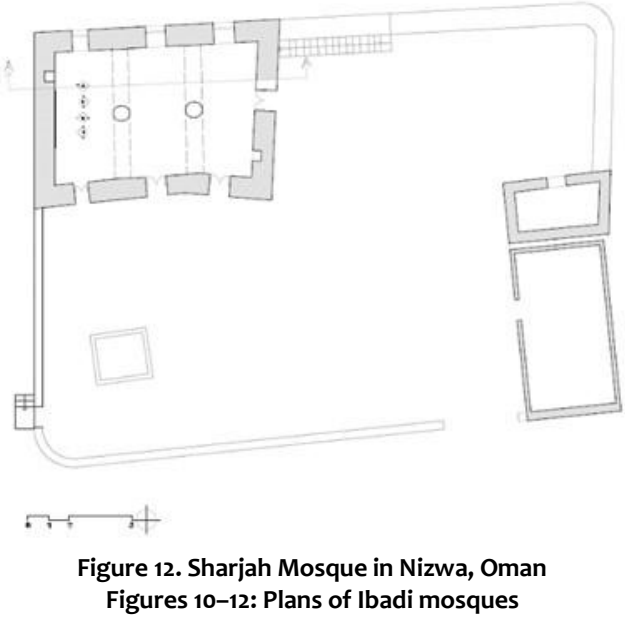

The courtyard (Sahn) does not seem to be a primary component of the architecture of the Ibadi mosques surveyed in this study. Instead, the configuration and proportions of the courtyard result, in most cases, from the form and the spatial organization of the prayer hall and the other parts of the mosque. While highlighting the presence of these characteris tics in the Maliki mosques in the M'zab, Djerba, and even in western Sudan, Schacht has traced their origins back to the Ibadi mosques of M'zab. He thus revealed the influence exerted by the Ibadi style on the religious architecture of neighboring regions. He asserts, The Ibadis not only disseminated the features of Islamic religious architecture throughout the Sahara, but they are also likely to have transmitted Islam itself to subSaharan Africa' [6]. However, this information does not help in the interpretation of this 'fragmented' organization of Ibadi mosque spaces. Nor does it help us understand the reason for which the courtyard does not have the same importance and regular forms as in classical Islamic religious architecture.

As mentioned earlier, this fragmentation is also almost omnipresent in the old mosques of Oman [7]. To explain it, one could advance the argument of adaptation to the extreme climate of the desert. For a certain period of the day, there is the need to hide from the unforgiving sun in a covered, enclosed space [8], [19]. However, the climatic factor alone is not enough to explain the unique spatial organization of the lbadi traditional mosque. The interpretation suggested by Mrabet is interesting to consider in this context. In fact, when he observed this particularity in the Ibadi mosques of Djerba, Mrabet argued that this organization is a sort of translation of the spatial organization of the holy site of Mecca, where the Kaaba is closed, in the center, and surrounded by the other spaces and elements that comprise the sacred place [8], [19]. It seems plausible that the Ibadis, in their conservative spirit and aspiration go back to the origins of the Islamic faith, would have taken the layout of the Kaaba complex as a model for their sacred buildings. However, none of the religious source texts consulted mentions this intention. In numerous textual references to these components, neither the location nor the dimensions of the prayer hall or the courtyard were evoked. The only affirmation consistently present in all these scholarly references is the fact that, although less important in the ritual practice, the sahn has the same status as the closed prayer room [15], [22], [23].

\section{ARCHITECTURAL ELEMENTS OF THE MOSQUE A- THE MINARET}

With the exception of the great mosques of the M'zab and the mosques of the defensive belt along the beach of Djerba, the absence of minarets is a recurrent character observable in the majority of the Ibadi mosques of this study. The descriptions by Al Bakri and Ibn Saghir about the great mosque of Tahart evoke a grandiose ornamented building flanked by towers [24] these descriptions do not, however, indicate the role of those towers for the mosque. Furthermore, the 
archaeological excavations of the site by Marguerite Van Berchem did not reveal the presence of any minaret [25]. The absence of minarets was also documented by researchers investigating the Ibadi mosques of Djerba [8] and Oman [14], [26]. Curiously, the numerous researchers who investigated the mosques and architecture of the M'zab did not mention this unusual phenomenon: any of the mosques in this region has a minaret, except the grand mosque.

How could one explain this phenomenon? What is the position of the Ibadi precepts about the minaret? And what could explain the exceptions observed?

Two interpretations of this phenomenon were proposed by researchers who revealed it in Djerba and Oman. First, Biancifiori considered that this particularity is the direct result of the practice of Ibadi rituals [14]. Mrabet believes the presence of minarets in some of the old mosques of Djerba to be directly related to their defensive role. He underlines that the typical Ibadi mosque in Djerba does not contain any minaret, as was the case of the first mosque built by the prophet of Islam, Muhammad [8].

As for the position expressed in the Ibadi scholarly references, they cannot be more transparent. Whether it be for the prayer call or protection, surveillance, or communication via signaling, the minaret is not considered an essential component of the mosque [15], [23]. Ibadi jurisprudential texts state clearly that the construction of a minaret is allowed if needed, but it should never be funded by the budget designated for the mosque [7].

The absence of a minaret is a phenomenon that has been observed in other non-lbadi mosques as well. Barrucand and Bednorz explain it as the will of the builders to refer back to the mosque of the prophet [8], [27]. This interpretation posits the existence of a tight relationship between the principles of the Ibadi doctrine and the absence of minarets in their mosques [5]. The minaret of the Ibadi mosque, when it exists, is not a ritual component. Instead, it could have a defensive function or another symbolic role. The source texts consulted do not describe the architectural aspect of this element; they do, however, indicate its position in the mosque: facing the Qabila wall [28] or adjacent to it [15].

\section{B- THE PROLIFERATION OF MIHRAB(S)}

Most of the Ibadi spaces for worship studied present additional prayer niches, to the point of proliferation [6], [19]. It is a peculiar aspect only observed in Ibadi mosques or those influenced by Ibadism. Based on our observation, the prayer spaces originally receive one Mihrab. The number of these is increased whenever the sanctuary is enlarged or modified. The enlargement of the courtyard or the prayer room sometimes requires the demolition of the Qabila wall where the Mihrab is usually situated. In such cases, the wall is eliminated, but its Mihrab is left intact. Thus, the number of Mihrab multiplies, while the prayer space is expanded over time, as was the case with the mosques of Baba Saad, Sidi Brahim, Beni Izguen and Ghardaia in M'zab [7].

\section{What is the origin of this practice?}

This feature is said to be specific to Ibadi mosques [8], [19]. Mrabet explains it by the symbolic importance of the Mihrab and the Qabila wall [8], [22]. A review of the building regulations detailed in Ibadi legal texts reveals that most of the scholars were unanimous in prohibiting the destruction of the Qabila wall of any lbadi mosque, even for its enlargement or consolidation [15], [23]. A few scholars tolerate the alteration of the Qabila wall for valid reasons, but they insist that the original Mihrab be retained, untouched. It seems that it is indeed this canonical position that can explain the phenomenon of Mihrab proliferation in Ibadi mosques.

\section{C- THE SIGNIFICANCE OF THE MINBAR}

While it is true that a Minbar is one of the features of the mosque that is directly linked to ritual precepts, its absence from the great mosques built by Ibadis is neither permanent nor systematic [7]. The presence of a Minbar in any mosque is a sign that this sanctuary is a Jama' ('great' mosque in which the Friday sermon and congregational prayer take place). The great mosques of the M'zab systematically lacked this element, highlighting the state of kitman in which the Ibadi community was living, in that it indicated the absence of a proclaimed imam for the community. The mosques in Oman that we studied were all equipped with a Minbar, while the mosques of Djerba vacillated between the status of Jama' and that of merely a masjid [8], [6], [19].

\section{What determines the absence or presence of the Min- bar in an Ibadi mosque?}

The great collective Friday prayer is not only a religious duty: it is essentially a political demonstration [6]. It cannot be performed in its ritual form that necessitates the presence of the Minbar unless all the conditions specified by Islamic law are met. The most important among those conditions is, in the view of the Ibadi scholars, the presence of an elected imam at the head of their community [6], [23]. When an imam is present, this is known as Zuhur (a state of proclamation or overtness). After the fall of the Imamate of Tahart, the Ibadi community went into a state of "Kitmân," and the imam was no longer elected. In such a situation, the congregational Friday prayer and the two Eid prayers are performed as regular prayers without a sermon, and thus there is no need for the Minbar [6].

In contrast to the situation in the Maghrib, the Ibadis of Oman were always led by elected imams and thus were in a state of Zuhur. Therefore, their great mosques are all equipped with a Minbar to be used for the sermon (Figures 13-15) [23]. We can conclude with Schacht that the absence or presence of the Minbar in the great mosques of the lbadis is determined by purely religious and ritual factors. More precisely, the pres- 
ence of the Minbar is due to the association of a religious requirement and a political state [6], [19].

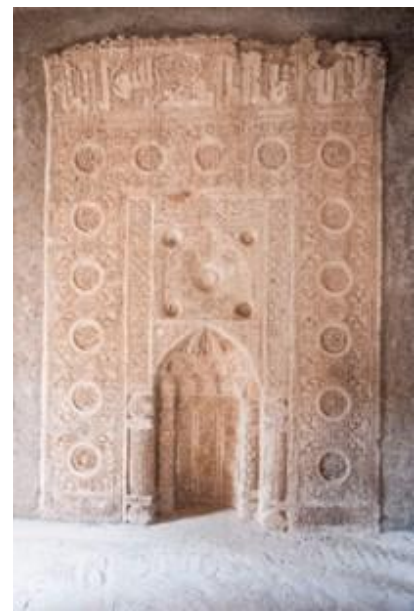

Figure 13. The Mihrab of Sharjah Mosque, Nizwa

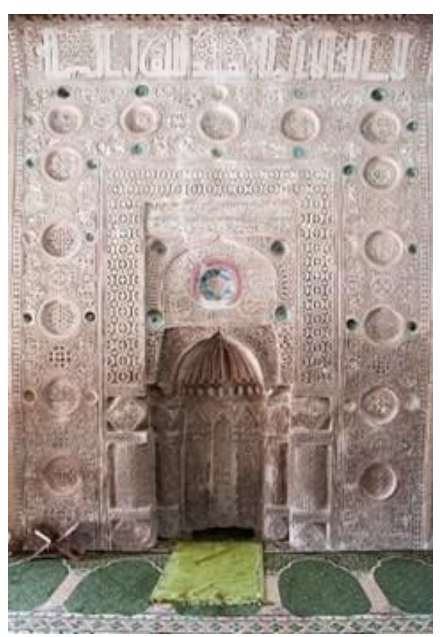

Figure 14. The Mihrab of Shawadna mosque, Nizwa.

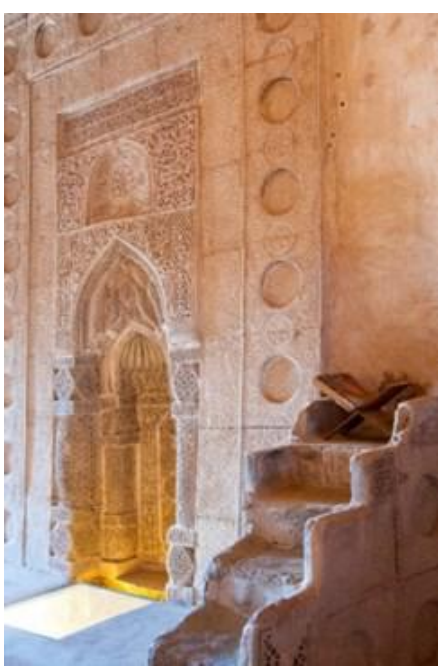

Figure 15. Ornamented Minbar of the Great Mosque of Bahla Figures 13-15: Examples of ornamented Mihrab(s) in M'zab and Djerba
The instability of the status of Jama's and the presence or lack of a Minbar in some of the Ibadi mosques of Djerba is a phenomenon linked to the evolution of the political and/or social situation on the island. During periods where the Ibadi inhabitants felt safe and were able to freely elect their representatives with the recognition of the Ibadi state wherever it appeared, they would build great mosques (e.g., Jama' Fadhloun and Walhi) and equip some of them with Minbar(s) for the congregational prayers [7][8]. In times where the situation became one of fear and oppression, those mosques were transformed into regular prayer spaces, and the sermon was not delivered. Nevertheless, we must allow that there may be more than a single explanation for this phenomenon. As expressed by Schacht, 'The exceptional presence of Minbar(s) in some Ibadi mosques in Djerba does not invalidate the conclusions that one can draw concerning their absence, overall, from the Ibadi mosques' [6].

\section{CONCLUSIONS AND PROSPECTS}

This article summarizes the architectural characteristics of Ibadi sanctuaries revealed by the systematic analysis of representative samples of this architecture in all the regions inhabited by Ibadi communities: M'zab, Djerba, Jebel Nafusa, and Oman. This study did not focus on the singularities of the religious architecture of the Ibadis in each site, as the aim was to reveal the common aspects characterizing this architecture in all the regions where it exists. These aspects form an "air de Famille," unifying the Ibadi mosques and distinguishing them from what is known as classical religious architecture in Islam. Once identified, these specificities were studied from the perspective of Ibadi teachings and jurisprudence. It has been established that the legal texts produced by this school of thought addressed some aspects of the religious architecture and seemed to have influenced, if not generated, some of the architectural features that we identified. At the same time, exceptions to the implementation of some of those regulations were revealed by the research. A certain number of these exceptions could not be explained by the current body of knowledge about Ibadi religious architecture. They deserve deeper investigation, which should re-new research to be undertaken in the future.

\section{REFERENCES}

[1] J. C. Wilkinson, "Changement et continuité en Oman," in La péninsule arabique, P. Bonnenfant, Eds, Paris: Editions CNRS, 1980, pp. 394-395.

[2] T. Lewicki, "Al-Ibadiyya”, in Encyclopedia of Islam, P.J. Bearman, Th. Bianquis, C.E. Bosworth, E. van Donzel, and W.P. Heinrichs, Eds, London: LeidenBrill, 1971, 3, pp. 648-660.

[3] M. Mercier, La civilisation urbaine au M'Zab, Etude de sociologie Africaine, Algiers: Imprimerie Emile Pfister, 1922. 
[4] C. \& P. Donnadieu, H. \& J-M. Didillon, Habiter le désert, les maisons mozabites: recherches sur un type d'architecture traditionnelle présaharienne, Brussels: Mardaga, 1977.

[5] A. Ravéreau, Le M'Zab, une leçon d'architecture, Paris: Sindbad, 1981.

[6] J. Schacht, "Sur la diffusion des formes d'architecture religieuse musulmane à travers le Sahara", in Travaux de l'Institut de Recherches, Tome XI, Sahariennes, 1954.

[7] N. Benkari, "A Document of Ibadi Fiqh Governing the Architecture of Mosques." Journal of Islamic Architecture, vol 4(2), pp. 56-62, December 2016.

[8] N. Benkari-Boudidah, L'Architecture des mosquees Ibadites: M'zab, Djerba et Oman. Principes de conception et de construction, vol. 2, Saarbrücken: Presses académiques francophones, 2014, pp 8388.

[9] R. Mrabet, Mudawwanat Masajid Djerba, Tunis: Institut National du Patrimoine, Ministry of Culture, 2002.

[10] J. Despois, Le djebel Nefousa: Etude géographique, Paris: Larose, 1935.

[11] B. Zevi, Apprendre à voir l'architecture, Paris: Editions de Minuit, 1959.

[12] M. Mercier, Etude sur le waqf abadhite et ses applications au Mzab. Alger: Jules Carbonel, 1927.

[13] H. Mu'nis, Al-Masajid, Kuwait: Al-Majlis al-Watani li I-Thaqafah wa I-Funun wa I-Adab [National Council on Culture, Arts, and Humanities], 1981.

[14] M. \& E. Gouvion, Le Kharedjisme: Monographie du Mzab, Casablanca: La Vigie Marocaine, 1926.

[15] M. A. Biancifiori, Works of Architectural Restoration in Oman, translated by S. Molton, Rome: De Luca, 1994.

[16] M.I. Y. Attafayyish, Sharh kitab al-nil wa shifa' al'alil [A commentary on al-Thamini's 'Kitab alnil' (19c.)], $2^{\text {nd }}$ ed., vol 17, Jeddah: Maktabat alIrshad, 1972.
[17] A. Z. Y. ibn A. B. Al-Warjilani, Kitab al-sirah wa akhbar al-a'imma fi tarikh ahl Mizab. Algiers: Delagrave, 1979.

[18] M. Mercier, "Notes sur une architecture berbère saharienne", Hespéris 8, 1928, pp. 413-429

[19] G. Marçais, Manuel d'art musulman, l'architecture: Tunisie, Algérie, Maroc, Espagne, Sicile, Paris: Auguste Picard, 1927.

[20] J. Schacht, "Notes Mozabites", Al Andalus, vol. XXII, fasc. 1, 1957.

[21] H. Saladin and G. Migeon, Manuel d'art musulman, Paris: A. Picard, 1907.

[22] Y. Bonète, "Notes sur l'architecture religieuse du M'Zab." Cahiers des arts et techniques d'Afrique du nord, no. 6, 1961.

[23] M. K. al-Battashi, Salasil al-dhahab, fil usul wa Ifar'i wa l-adab, Muscat: Ministry of Heritage and Culture, 1990.

[24] A. B. A. B. A. B. Moussa, "Al Kindi A'Samadî Al Nizwî : Al Muçannaf, écrit en 1162, présenté en Arabe moderne par Abdelmon im 'Amer” in Ministère du patrimoine et de la culture, Dr. Jâdallah Ahmad, Eds, volume 5, Oman, 1983.

[25] A. d. C. Motylinski, "Chronique d'Ibn Saghir : sur les imams Rostemides de Tahert", Actes du XIVe congrès international des Orientalistes, Algiers, 1905.

[26] M. V. Berchem, "À la recherche de Sedrata: deux campagnes de fouilles sur le site de l'ancienne capitale ibadite", Algeria et l'Afrique du nord illustrée, Oct. 1953, no. 33 http://alger-roi.fr/Alger/ tourisme/textes/3 sedrata algeria33.htm Accessed 2 Jun 2016

[27] P. M. Costa, "Historic Mosques and Shrines of Oman", BAR International Series, 938, Oxford: Archaeopress, 2001.

[28] M. Barrucand and A. Bednorz, L'architecture maure en Andalousie, Cologne: Taschen, 1992. 